\title{
ENHANCING STUNDENT'S SCIENTIFIC ATTITUDE USING INQUIRY LEARNING MODELS FOR SCIENCE SUBJECT CLASSROOM IN 5TH GRADE STUDENT OF SD NEGERI PRAWIT I NO.69 YEAR OF ACADEMIC 2017/2018
}

\section{Ermi Widyaningsih, Jenny Indrastoeti Siti Poerwanti, Chumdari}

Universitas Sebelas Maret ermiwidya354@gmail.com

\section{Article History}

accepted 09/07/2018

approved 01/08/2018

published 17/09/2018

\section{Keywords}

inquiry, scientific approach, scientific classroom

\begin{abstract}
The aim of this research is to enhance the student's scientific attitude using inquiry learning method in the science classroom. This study used classroom action research method done in three cycles. Every cycle provide planning, acting, observing and reflecting. The method of collecting data used observation, interview and documentation. Technique triangulation, source triangulation and informant review used to check the data validity. Data analysis technique used in this study was interactive model. The conclusion of this research showed the use of inquiry learning succesfully enhance student's scientific attitude for science classroom in 5th grade of SD Negeri Prawit 1 No. 69 Surakarta year of academic 2017/2018.
\end{abstract}

Social, Humanities, and Education Studies (SHEs): Conference Series https://jurnal.uns.ac.id/shes
p-ISSN 2620-9284 e-ISSN 2620-9292 


\section{PENDAHULUAN}

Proses pembelajaran merupakan aktivitas utama dalam pendidikan. Ngalimun (2016:3) menjelaskan bahwa pembelajaran peserta didik memperoleh keterampilanketerampilan yang spesifik, pengetahuan, dan sikap, dengan kata lain pembelajaran yang spesifik akan terjadi apabila ke tiga ranah pembelajaran yang spesifik akan terjadi apabila ke tiga ranah pembelajaran tercapai.

Ilmu Pengetahuan Alam (IPA) adalah ilmu yang mempelajari alam dengan segala isinya, atau suatu kumpulan pengetahuan yang tersusun secara sistematis tentang gejala alam (Sukardjo, $2005:$ 1). IPA merupakan salah satu mata pelajaran di Sekolah Dasar (SD). Pembelajaran IPA di SD dilaksanakan dengan penyelidikan sederhana terhadap kumpulan konsep IPA, sehingga akan memberikan pengalaman langsung melalui pengamatan, diskusi, dan penyelidikan sederhana (Susanto, 2016:170).

Jenjang pendidikan SD merupakan waktu yang tepat dalam penanaman karakter sebagai pondasi dalam pembentukan kepribadian diri. Sikap merupakan kesiapan merespon secara konsisten dalam bentuk positif atau negatif terhadap objek atau situasi. Sikap ilmiah adalah kecenderungan pibadi ilmuan untuk berperilaku atau memberikan tanggapan dengan pemikiran ilmiahnya (Gie, 1995:52). 42). Bundu (2006:13) mendefinisikan bahwa sikap Sains merupakan sikap yang dimiliki para ilmuan dalam mencari dan mengembangkan pengetahuan baru, seperti sikap objektif terhadap fakta, hati-hati, bertanggung jawab, berhati terbuka, selalu ingin meneliti, dan sebagainya. Dimensi sikap ilmiah berdasarkan literatur yang telah dikaji, diantaranya (1) toleransi, (2) jujur, (3) disiplin, (4) rasa ingin tahu, (5) kerja keras, dan (6) mandiri.

Guru merupakan fasilitator dalam proses pembelajaran, guru bukan hanya menjadi sumber informasi bagi peserta didik namun bertugas memfasilitasi pembelajaran dengan membimbing dan mengajak semua peserta didik untuk aktif berpartisipasi dalam pembelajaran. Sehingga tujuan pembelajaran baik secara pengetahuan, sikap, dan keterampilan dapat ditingkatkan. Penerapan model pembelajaran Inquiry untuk meningkatkan sikap ilmiah siswa pada pembelajaran IPA. Model pembelajaran Inquiry mencipatakan sebuah pembelajaran yang kondusif aktif dan menyenangkan. Siswa ditekankan untuk aktif dalam proses pembelajaran dengan menemukan sendiri pengetahuan melalui kegiatan percobaan, sehingga dapat membiasakan siswa untuk bekerja layaknya seorang ilmuan.

Berdasarkan hasil observasi pratindakan pada 31 Januari 2018 diketahui bahwa sikap ilmia siswa masih rendah. Hal tersebut dibuktikan dari adanya beberapa fakta mengenai sikap ilmiah siswa, diantaranya: (1) beberapa siswa tidak memperhatikan penjelasan guru, (2) sedikit siswa yang antusias merespon pertanyaan guru, (3) siswa cenderung pasif dalam melakukan kegiatan selama pembelajaran, (4) beberapa siswa belum bersungguh-sungguh, dan (5) beberapa siswa tidak tepat waktu dalam menyelesaikan tugas. Hal tersebut diperkuat dengan hasil observasi yang menunjukkan bahwa hanya terdapat 8 siswa atau 44,44\% siswa yang memiliki kategori sikap ilmiah baik dari persentase ketuntasan klasikal yang ditentukan.

Hasil observasi tersebut diperkuat dengan adanya wawacara dengan guru kelas pada pembelajaran IPA, ditunjukkan adanya beberapa masalah diantaranya: proses pembelajaran belum mampu menumbuhkan sikap ilmiah siswa, penerapan model pembelajaran belum bervariatif, siswa belum terbiasa dengan kegiatan percobaan dan penggunaan media pembelajaran, dan pembelajaran masih bersifat teacher centered learning. Pembelajaran dengan mengutamakan metode ceramah bukan berarti tidak dapat berpengaruh pada hasil belajar siswa. Namun, pembelajaran hanya akan menekankan pada hasil kognitif saja, sedangkan kedua ranah yang lain seperti psikomotorik dan sikap terutama akan lebih susah ditingkatkan. Karena siswa tidak dilatih dan tidak terfasilitasi untuk mengembangkan sikap ilmiah. 
Model pembelajaran Inquiry merupakan model pembelajaran cukup akomodatif untuk pembelajaran IPA di SD, model tersebut menjadi jembatan model pembelajaran konvensional yang masih menekankan pada verbalitas dan minim media ke gaya pembelajaran IPA yang alternatif dan lebih proprosioal bagi hakikat sains dan karakteristik siswa SD (Fatonah \& Prasetyo, 2014:74). Pada penerapan model pembelajaran Inquiry guru tidak lagi sebagai sumber belajar, guru berkedudukan sebagai fasilitator dan membimbing siswa dalam belajar yang sesuai dengan orientasi yang telah diberikan guru diawal pembelajaran. Sehingga siswa dituntut untuk berpartisipasi aktif dalam pembelajaran melaui kegiatan percobaan atau eksperimen.

\section{METODE}

Penelitian ini merupakan jenis penelitian tindakan kelas (PTK) dengan model siklus. PTK merupakan tindakan nyata (action) yang dilakukan guru (dan bersama pihak lain) untuk memecahkan masalah yang dihadapi didalam proses belajar mengajar (Suwandi \& Sarwiji, 2009:11). Penelitian ini dilaksanakan di kelas V SD Negeri Prawit I No.69 Surakarta pada semester II tahun ajaran 207/208. Penelitian ini dilaksanakan selama 6 bulan. Subjek penelitian ini adalah guru dan siswa, sejumlah 18 siswa. Penelitian tindakan kelas ini dilakukan sebanyak III siklus. Setiap siklus dilaksanakan dalam dua pertemuan yang terdiri dari empat tahapan yaitu, perencanaan, tindakan, observasi, dan evaluasi-refleksi. Sumber data berasal dari guru dan siswa. Bentuk data yang didapatkan berupa hasil pengamatan sikap ilmiah siswa dan kinerja guru melalui hasil observasi siswa, hasil wawancarara guru dan siswa, serta dokumen yang terdiri dari silabus IPA kelas V, RPP IPA kelas V, dan dilengkapi denga foto dan video pelaksanaan tindakan. Teknik pengumpulan data yang digunakan adalah trianggulasi sumber, trianggulasi teknik, dan review informan. Teknik analisis data yang digunakan adalah teknik analisis interaktif.

\section{HASIL DAN PEMBAHASAN}

Berdasarkan hasil pengamatan pratindakan sikap ilmiah siswa kelas V SD Negeri Prawit I No.69 Surakarta belum memiliki sikap ilmiah yang termasuk dalam kategori baik. Hasil pengamatan sikap ilmiah siswa kelas $\mathrm{V}$ pada pratindakan dapat dilihat pada Tabel 1:

Tabel 1. Sikap IImiah Pratindakan

\begin{tabular}{|c|c|c|c|c|}
\hline \multirow[t]{2}{*}{ Skor } & \multirow[t]{2}{*}{ Frekuensi } & \multicolumn{2}{|c|}{$\%$} & \multirow[t]{2}{*}{ Kategori } \\
\hline & & Relatif & Kumulatif & \\
\hline 25 & 1 & 5,56 & 5,56 & Kurang \\
\hline 27 & 2 & 11,11 & 16,67 & Kurang \\
\hline 28 & 3 & 16,66 & 33,33 & Cukup \\
\hline 29 & 3 & 16,66 & 49,99 & Cukup \\
\hline 30 & 1 & 5,56 & 55,55 & Cukup \\
\hline 32 & 4 & 22,22 & 77,77 & Baik \\
\hline 33 & 2 & 11,11 & 88,88 & Baik \\
\hline 35 & 1 & 5,56 & 94,44 & Baik \\
\hline 40 & 1 & 5,56 & 100,00 & Sangat Baik \\
\hline Total & 18 & 100 & & \\
\hline \multicolumn{5}{|c|}{ Skor rata-rata kelas $30,48(\mathrm{C})$} \\
\hline \multicolumn{5}{|c|}{ Persentase Ketuntasan Klasikal (Skor $\geq 36$ ) 44,44\% } \\
\hline \multicolumn{5}{|c|}{ Skor tertinggi 40} \\
\hline Skor tere & 25 & & & \\
\hline
\end{tabular}


Berdasar Tabel 1 tersebut ditunjukkan bahwa hasil observasi yaitu bahwa hanya terdapat 1 siswa atau 5,56\% kategori sangat baik, 7 siswa atau 38,88\% kategori baik, 7 siswa atau 38,88\% kategori cukup, dan 3 siswa atau 16,67\% kategori kurang. Sehingga dapat dibuat klasifikasi kategori sikap ilmiah pratindakan Tabel 2 berikut ini:

Tabel 2. Kategori Sikap Ilmiah Pratindakan

\begin{tabular}{cccc}
\hline Interval & Kategori & $\begin{array}{c}\text { Frekuensi } \\
\text { (siswa) }\end{array}$ & $\begin{array}{c}\text { Persentase } \\
\text { (\%) }\end{array}$ \\
\hline $24-27$ & Kurang & 3 & 16,67 \\
$28-31$ & Cukup & 7 & 38,89 \\
$32-35$ & Baik & 7 & 38,88 \\
$36-39$ & Sangat Baik & 1 & 5,56 \\
\hline \multicolumn{2}{c}{ Jumlah } & $\mathbf{1 8}$ & $\mathbf{1 0 0}$ \\
\hline
\end{tabular}

Berdasarkan hasil sajian pada Tabel 1 dan Tabel 2, dapat diketahui bahwa sikap ilmiah siswa masih jauh dari indikator kinerja yang ditentukan yaitu $(\geq 80)$ atau 16 siswa memiliki kategori baik. Sehingga, dilaksanakan siklus I pertemuan I dan pertemuan II. Pada siklus I peneliti menerapkan model Inquiry dalam pembelajaran IPA pokok bahasan gaya dan hasinya disajikan dalam tabel berikut ini:

Tabel 3. Sikap Ilmiah Tahap Siklus I Pertemuan 1

\begin{tabular}{|c|c|c|c|c|}
\hline \multirow[t]{2}{*}{ Skor } & \multirow[t]{2}{*}{ Frekuensi } & \multicolumn{2}{|c|}{$\%$} & \multirow[t]{2}{*}{ Kategori } \\
\hline & & Relatif & Kumulatif & \\
\hline 5 & 3 & 16,67 & 16,67 & Kurang \\
\hline 6 & 1 & 5,56 & 22,23 & Kurang \\
\hline 8 & 1 & 5,56 & 27,79 & Cukup \\
\hline 9 & 1 & 5,56 & 33,35 & Cukup \\
\hline 10 & 2 & 11,11 & 44,46 & Cukup \\
\hline 11 & 2 & 11,11 & 55,57 & Baik \\
\hline 12 & 1 & 5,56 & 61,13 & Baik \\
\hline 13 & 1 & 5,55 & 66,68 & Baik \\
\hline 14 & 1 & 5,55 & 72,23 & Sangat Baik \\
\hline 15 & 1 & 5,55 & 77,78 & Sangat Baik \\
\hline 17 & 1 & 5,55 & 83,33 & Sangat Baik \\
\hline 18 & 3 & 16,67 & 100,00 & Sangat Baik \\
\hline Total & 18 & 100 & & \\
\hline $\begin{array}{l}\text { Skor rat } \\
\text { Persent } \\
\text { Skor ter } \\
\text { Skor ter }\end{array}$ & $\begin{array}{l}\text { ta kelas 11, } \\
\text { Ketuntasan } \\
\text { gi } 18 \\
\text { lah } 5\end{array}$ & $\begin{array}{l}\text { Baik) } \\
\text { sikal }(\geq 1\end{array}$ & $5,56 \%$ & \\
\hline
\end{tabular}

Berdasar Tabel 2 sikap ilmiah siklus I pertemuan 1 menunjukkan dari 18, terdapat 6 siswa atau 33,34\% kategori sangat baik, 4 siswa atau 22,22\% kategori baik, 4 siswa atau 22,22\% kategori cukup, dan 4 siswa atau 22,22\% kategori kurang . Sehingga dapat dibuat klasifikasi kategori sikap ilmiah siklus I pertemuan 1 yang tertera pada Tabel 4.17 berikut ini: 
Tabel 4. Kategori Sikap IImiah Siklus I Pertemuan 1

\begin{tabular}{|c|c|c|c|}
\hline Interval & Kategori & $\begin{array}{c}\text { Frekuensi } \\
\text { (siswa) }\end{array}$ & $\begin{array}{c}\text { Persentase } \\
(\%)\end{array}$ \\
\hline $5-7$ & Kurang & 4 & 22,22 \\
\hline $8-10$ & Cukup & 4 & 22,22 \\
\hline $11-13$ & Baik & 4 & 22,22 \\
\hline $14-16$ & Sangat Baik & 6 & 22,22 \\
\hline \multicolumn{2}{|c|}{ Jumlah } & 18 & 100 \\
\hline
\end{tabular}

Berdasarkan tabel rata-rata sikap ilmiah pada siklus I pertemuan 1, menunjukkan bahwa nilai rata-rata sikap ilmiah pada siklus I pertemuan 1 mencapai indikator kinerja penelitian, sehingga dilakukan tindakan siklus I pertemuan 2.

Tabel 5. Sikap Ilmiah Siklus I Pertemuan 2

\begin{tabular}{|c|c|c|c|c|}
\hline \multirow[t]{2}{*}{ Skor } & \multirow[t]{2}{*}{ Frekuensi } & \multicolumn{2}{|c|}{$\%$} & \multirow[t]{2}{*}{ Kategori } \\
\hline & & Relatif & Kumulatif & \\
\hline 6 & 1 & 5,55 & 5,55 & Kurang \\
\hline 8 & 1 & 5,55 & 11,10 & Kurang \\
\hline 9 & 1 & 5,55 & 16,65 & Cukup \\
\hline 11 & 1 & 5,55 & 22,20 & Cukup \\
\hline 12 & 2 & 11,11 & 33,31 & Cukup \\
\hline 13 & 1 & 5,55 & 38,86 & Cukup \\
\hline 15 & 3 & 16,67 & 55,53 & Baik \\
\hline 19 & 1 & 5,56 & 61,09 & Baik \\
\hline 20 & 1 & 5,56 & 66,65 & Sangat Baik \\
\hline 22 & 1 & 5,56 & 72,21 & Sangat Baik \\
\hline 25 & 2 & 11,11 & 83,32 & SangatBaik \\
\hline 26 & 1 & 5,56 & 88,88 & Sangat Baik \\
\hline 27 & 1 & 5,56 & 94,44 & Sangat Baik \\
\hline 28 & 1 & 5,56 & 100 & Sangat Baik \\
\hline Total & 18 & 100 & & \\
\hline \multicolumn{5}{|c|}{$\begin{array}{l}\text { Skor rata-rata kelas 17,11 (Baik) } \\
\text { Persenatse Ketuntasan Klasikal (Skor } \geq 14) 61,11 \% \\
\text { Skor tertinggi } 28 \\
\text { Skor terendah } 6\end{array}$} \\
\hline
\end{tabular}

Berdasar Tabel 5 sikap ilmiah siklus I pertemuan 2 menunjukkan dari 18, 7 siswa atau 38,89\% kategori sangat baik, 4 siswa atau 22,22\% kategori baik, 4 siswa atau $22,22 \%$ kategori cukup, dan 3 siswa atau 16,67\% kategori kurang. Sehingga dibuat klasifikasi kategori sikap ilmiah siklus I pertemuan 2 yang tertera pada Tabel 4.27 berikut ini;

Tabel 6. Kategori Sikap IImiah Siklus I Pertemuan 2

\begin{tabular}{|c|c|c|c|}
\hline Interval & Kategori & $\begin{array}{c}\text { Frekuensi } \\
\text { (siswa) }\end{array}$ & $\begin{array}{c}\text { Persentase } \\
(\%)\end{array}$ \\
\hline $5-9$ & Kurang & 3 & 16,67 \\
\hline $10-14$ & Cukup & 4 & 22,22 \\
\hline $15-19$ & Baik & 4 & 22,22 \\
\hline $20-24$ & Sangat Baik & 7 & 38,89 \\
\hline \multicolumn{2}{|c|}{ Jumlah } & 18 & 100 \\
\hline
\end{tabular}


Data pada siklus I menunjukkan belum tercapainya indikator kinerja penelitian yang telah ditentukan yaitu $(\geq 80 \%)$ dengan kategori baik, Maka dilaksanakan tindakan siklus II dengan pertemuan 1 dan pertemuan 2 yang didasarkan dari hasil refleksi dan evaluasi pada siklus I. Pada tahap siklus II menerapkan model pembelajaran Inquiry dalam pembelajaran IPA pokok bahasan pesawat sederhana dan tabel data sikap ilmiah siswa pada pelaksanaan siklus II pertemuan 1 disajikan pada Tabel 7 berikut ini:

Tabel 7. Sikap IImiah Tahap Siklus II pertemuan 1

\begin{tabular}{|c|c|c|c|c|}
\hline \multirow[t]{2}{*}{ Skor } & \multirow[t]{2}{*}{ Frekuensi } & \multicolumn{2}{|c|}{$\%$} & \multirow[t]{2}{*}{ Kategori } \\
\hline & & Relatif & Kumulatif & \\
\hline 11 & 1 & 5,56 & 5,56 & Kurang \\
\hline 12 & 1 & 5,56 & 11,12 & Kurang \\
\hline 16 & 1 & 5,56 & 16,68 & Cukup \\
\hline 17 & 1 & 5,56 & 22,24 & Cukup \\
\hline 18 & 1 & 5,56 & 27,80 & Cukup \\
\hline 22 & 3 & 16,67 & 44,47 & Baik \\
\hline 23 & 1 & 5,56 & 50,03 & Baik \\
\hline 24 & 1 & 5,55 & 55,58 & Baik \\
\hline 25 & 1 & 5,55 & 61,13 & SangatBaik \\
\hline 26 & 1 & 5,55 & 66,68 & Sangat Baik \\
\hline 27 & 1 & 5,55 & 72,23 & Sangat Baik \\
\hline 28 & 3 & 16,67 & 88,90 & Sangat Baik \\
\hline 29 & 1 & 5,55 & 94,45 & Sangat Baik \\
\hline 31 & 1 & 5,55 & 100,00 & Sangat Baik \\
\hline Total & 18 & 100 & & \\
\hline \multicolumn{5}{|c|}{ Skor rata-rata kelas 22,72 (Baik) } \\
\hline \multicolumn{5}{|c|}{ Persentase Ketuntasan Klasikal (Skor $\geq 20$ ) 61,11\%) } \\
\hline \multicolumn{5}{|c|}{ Skor tertinggi 31} \\
\hline \multicolumn{5}{|c|}{ Skor terendah 11} \\
\hline
\end{tabular}

Berdasar Tabel 7 sikap ilmiah siklus II pertemuan 1 menunjukkan dari 18, terdapat 8 siswa atau 44,44\% kategori sangat baik, 5 siswa atau 27,78\% kategori baik, 3 siswa atau 16,67\% kategori cukup, dan 2 siswa atau $11,11 \%$ kategori kurang Sehingga dapat dibuat klasifikasi kategori sikap ilmiah siklus II pertemuan 1 pada Tabel 8 sebagai berikut:

Tabel 8. Kategori Sikap IImiah Siklus II Pertemuan 1

\begin{tabular}{|c|c|c|c|}
\hline Interval & Kategori & $\begin{array}{l}\text { Frekuensi } \\
\text { (siswa) }\end{array}$ & $\begin{array}{c}\text { Persentase } \\
(\%)\end{array}$ \\
\hline $10-14$ & Kurang & 2 & 11,11 \\
\hline $15-19$ & Cukup & 3 & 16,67 \\
\hline $20-24$ & Baik & 5 & 27,78 \\
\hline $25-29$ & Sangat Baik & 8 & 44,44 \\
\hline \multicolumn{2}{|c|}{ Jumlah } & 18 & 100 \\
\hline
\end{tabular}

Berdasarkan tabel rata-rata sikap ilmiah pada siklus II pertemuan 1, menunjukkan bahwa nilai rata-rata sikap ilmiah pada siklus II pertemuan 1 mencapai indikator kinerja penelitian, sehingga dilakukan tindakan siklus II pertemuan 2. 
SHEs: Conference Series 1 (1) (2018) 253-263

Tabel 9. Distribusi Frekuensi Sikap IImiah Siklus II Pertemuan 2

\begin{tabular}{ccccc}
\hline Skor & Frekuensi & \multicolumn{2}{c}{$\%$} & Kategori \\
& \multicolumn{5}{c}{ Relatif } & Kumulatif & \\
\hline 22 & 2 & 11,11 & 11,11 & Kurang \\
24 & 2 & 11,11 & 22,22 & Cukup \\
27 & 2 & 11,11 & 33,33 & Baik \\
28 & 1 & 5,56 & 38,89 & Baik \\
29 & 1 & 5,56 & 44,45 & Baik \\
30 & 1 & 5,56 & 50,01 & Sangat Baik \\
31 & 4 & 22,22 & 72,23 & Sangat Baik \\
32 & 3 & 16,66 & 88,89 & Sangat Baik \\
33 & 1 & 5,56 & 94,45 & Sangat Baik \\
35 & 1 & 5,55 & 100,00 & Sangat Baik \\
\hline Total & $\mathbf{1 8}$ & $\mathbf{1 0 0}$ & \\
\hline Skor rata-rata kelas 28,94 (Baik) \\
Persentase Ketuntasan Klasikal (Skor $\geq 30)$ 77,78\% \\
Skor tertinggi 35 \\
\multicolumn{5}{l}{ Skor terendah 22 }
\end{tabular}

Berdasar Tabel 9 sikap ilmiah siklus II pertemuan 2 menunjukkan dari 18, terdapat 10 siswa atau 55,56\% kategori sangat baik, 4 siswa atau 22,22\% kategori baik, 2 siswa atau 11,11\% kategori cukup, dan 2 siswa atau 11,11\% kategori kurang. Sehingga dapat dibuat klasifikasi kategori sikap ilmiah siklus II pertemuan 2 pada Tabel 10 sebagai berikut:

Tabel 10. Kategori Sikap IImiah Siklus II Pertemuan 2

\begin{tabular}{cccc}
\hline Interval & Kategori & $\begin{array}{c}\text { Frekuensi } \\
\text { (siswa) }\end{array}$ & $\begin{array}{c}\text { Persentase } \\
(\%)\end{array}$ \\
\hline $21-23$ & Kurang & 2 & 11,11 \\
$24-26$ & Cukup & 2 & 11,11 \\
$27-29$ & Baik & 4 & 22,22 \\
$30-32$ & Sangat Baik & 10 & 55,56 \\
\hline \multicolumn{2}{c}{ Jumlah } & $\mathbf{1 8}$ & $\mathbf{1 0 0}$ \\
\hline
\end{tabular}

Data tindakan siklus II menunjukkan belum tercapainya indikator kinerja yang telah ditentukan yaitu $(\geq 80 \%)$ dengan kategori baik. Maka dilaksanakan tindakan siklus III. Pelaksanaan tindakan didasarkan dari hasil refleksi dan evaluasi pada siklus II. Pada tahap siklus III menerapkan model pembelajaran Inquiry dalam pembelajaran IPA pokok bahasan sifat-sifat cahaya dan data sikap ilmiah siswa siklus III disajikan pada tabel berikut ini: 
SHEs: Conference Series 1 (1) (2018) 253-263

Tabel 11. Distribusi Frekuensi Sikap IImiah Siklus III Pertemuan 1

\begin{tabular}{|c|c|c|c|c|}
\hline \multirow[t]{2}{*}{ Skor } & \multirow[t]{2}{*}{ Frekuensi } & \multicolumn{2}{|c|}{$\%$} & \multirow[t]{2}{*}{ Kategori } \\
\hline & & Relatif & Kumulatif & \\
\hline 18 & 1 & 5,56 & 5,56 & Kurang \\
\hline 20 & 1 & 5,56 & 11,12 & Kurang \\
\hline 23 & 1 & 5,56 & 16,68 & Cukup \\
\hline 24 & 1 & 5,56 & 22,24 & Cukup \\
\hline 25 & 2 & 11,11 & 33,35 & Cukup \\
\hline 26 & $\overline{1}$ & 5,56 & 38,91 & Baik \\
\hline 27 & 1 & 5,56 & 44,47 & Baik \\
\hline 28 & 1 & 5,56 & 50,03 & Baik \\
\hline 29 & 1 & 5,55 & 55,58 & Baik \\
\hline 31 & 1 & 5,55 & 61,13 & Sangat Baik \\
\hline 33 & 3 & 16,66 & 77,79 & Sangat Baik \\
\hline 34 & 1 & 5.55 & 83,34 & Sangat baik \\
\hline 35 & 2 & 11,11 & 94,45 & Sangat Baik \\
\hline 36 & 1 & 5,55 & 100,00 & Sangat Baik \\
\hline Total & 18 & 100 & & \\
\hline \multicolumn{5}{|c|}{$\begin{array}{l}\text { Skor rata-rata kelas 28,61 (Baik) } \\
\text { Persentase Ketuntasan Klasikal (Skor } \geq 26) 66,67 \% \\
\text { Skor tertinggi } 36 \\
\text { Skor terendah } 18\end{array}$} \\
\hline
\end{tabular}

Berdasar Tabel 11 hasil observasi sikap ilmiah siklus III pertemuan 1, dari 18 siswa, 8 siswa atau 44,44\% kategori sangat baik, 4 siswa atau 22,22\% kategori baik, 4 siswa atau 22,22\%, dan 2 siswa atau 11,11\% kategori kurang (lampiran). Sehingga dapat dibuat klasifikasi kategori sikap ilmiah siklus III pertemuan 1 pada Tabel 12:

Tabel 12. Kategori Sikap IImiahSiklus III Pertemuan 1

\begin{tabular}{cccc}
\hline Interval & Kategori & $\begin{array}{c}\text { Frekuensi } \\
\text { (siswa) }\end{array}$ & $\begin{array}{c}\text { Persentase } \\
(\%)\end{array}$ \\
\hline $16-20$ & Kurang & 2 & 11,11 \\
$21-25$ & Cukup & 4 & 22,22 \\
$26-30$ & Baik & 4 & 22,22 \\
$31-35$ & Sangat Baik & 8 & 44,44 \\
\hline \multicolumn{2}{c}{ Jumlah } & $\mathbf{1 8}$ & $\mathbf{1 0 0}$ \\
\hline
\end{tabular}

Berdasarkan tabel rata-rata sikap ilmiah pada siklus III pertemuan 1, menunjukkan bahwa nilai rata-rata sikap ilmiah pada siklus III pertemuan 1 mencapai indikator kinerja penelitian $(\geq 80)$ dengan kategori baik, sehingga dilakukan kembali tindakan siklus III pertemuan 2. 
SHEs: Conference Series 1 (1) (2018) 253-263

Tabel 13. Distribusi Frekuensi Sikap IImiah Siklus III Pertemuan 2

\begin{tabular}{|c|c|c|c|c|}
\hline \multirow[t]{2}{*}{ Skor } & \multirow[t]{2}{*}{ Frekuensi } & \multicolumn{2}{|c|}{$\%$} & \multirow[t]{2}{*}{ Kategori } \\
\hline & & Relatif & Kumulatif & \\
\hline 25 & 1 & 5,56 & 5,56 & Kurang \\
\hline 26 & 1 & 5,56 & 11,12 & Cukup \\
\hline 28 & 1 & 5,56 & 16,68 & Cukup \\
\hline 29 & 2 & 11,11 & 27,79 & Baik \\
\hline 31 & 4 & 22,22 & 50,01 & Baik \\
\hline 32 & 2 & 11,11 & 61,12 & Sangat Baik \\
\hline 33 & 1 & 5,56 & 66,68 & Sangat Baik \\
\hline 34 & 5 & 27,77 & 94,45 & Sangat Baik \\
\hline 36 & 1 & 5,55 & 5,55 & Sangat Baik \\
\hline Total & 18 & 100 & & \\
\hline
\end{tabular}

Skor rata-rata kelas 31,33

Ketercapaian Indikator Kinerja (Skor $\geq 27,1$ ) 88,89\%

Skor tertinggi 36

Skor terendah 25

Berdasar Tabel 13 hasil observasi sikap ilmiah siswa siklus III pertemuan 2 menunjukkan dari 18 siswa, terdapat 9 siswa atau 50,00\% kategori sangat baik, 6 siswa atau 33,33\% kategori baik, 2 siswa atau 11,11\% kategori cukup, dan 1 siswa atau $5,56 \%$ kategori kurang. Sehingga dapat dibuat klasifikasi kategori sikap ilmiah siklus III pertemuan 2 pada Tabel 14 sebagai berikut:

Tabel 4.14. Kategori Sikap IImiah Siklus III Pertemuan 2

\begin{tabular}{cccc}
\hline Interval & Kategori & $\begin{array}{c}\text { Frekuensi } \\
\text { (siswa) }\end{array}$ & $\begin{array}{c}\text { Persentase } \\
(\%)\end{array}$ \\
\hline $23-25$ & Kurang & 1 & 5,56 \\
$26-28$ & Cukup & 2 & 11,11 \\
$29-31$ & Baik & 6 & 33,33 \\
$32-34$ & Sangat Baik & 9 & 50,00 \\
\hline \multicolumn{2}{c}{ Jumlah } & $\mathbf{1 8}$ & $\mathbf{1 0 0}$ \\
\hline
\end{tabular}

Berdasar pada data yang disajikan, diketahui bahwa terdapat peningkatan sikap ilmiah siswa kelas V SD Negeri Prawit I No.69 Surakarta dari pratindakan hingga siklus III. Perkembangan sikap ilmiah pada tahap pratindakanhingga siklus III dapat dilihat pada data perbandingan nilai sikap ilmiah yang masuk dalam kategori sangat baik yang disajikan dengan Tabel 15 sebagai berikut:

Tabel 15. Perkembangan Ketrecapaian Indikator Kinerja

\begin{tabular}{clcc}
\hline No. & Keterangan & \multicolumn{2}{c}{ Ketercapaian Indikator Kinerja } \\
& & Frekuensi Siswa & Persentase (100\%) \\
\hline 1. & Pratindakan & 8 & 44,44 \\
2. & Siklus I Pertemuan 1 & 10 & 55,56 \\
3. & Siklus I Pertemuan 2 & 11 & 61,11 \\
4. & Siklus II Pertemuan 1 & 13 & 72,22 \\
5. & Siklus II Pertemuan 2 & 14 & 77,78 \\
6. & Siklus III Pertemuan 1 & 12 & 66,67 \\
7. & Siklus III Pertemuan 2 & 15 & 83,33 \\
\hline
\end{tabular}


Perkembangan sikap ilmiah yang terjadi pada tindakan yang telah dilakukan dengan menerapkan model pembelajaran Inquiry, sikap ilmiah siswa dapat muncul dan membudaya serta mengalami peningkatan secara bertahap. Hal tersebut terjadi karena model tersebut menuntut keaktifan dan partisipasi siswa dalam proses pembelajaran serta melatih siswa dalam menemukan sendiri pengetahuan dalam pembelajaran dengan adanya percobaan, sehingga harapannya dapat membuat siswa dapat lebih menguasai mengenai materi yang disampaikan oleh guru. Fakta tersebut sesuai dengan pendapat Hosnan (2014:341) menyebutkan bahwa pembelajaran Inquiry membunyai karakteristik diantaranya: (1) menekankan pada aktivitas peserta didik, (2) seluruh aktivitas peserta diidk diarahkan untuk mencari, menemukan jawaban sendiri, (3) peserta didik tidak hanya dituntut menguasai materi namun menggunakan potensi yang dimilki. Hal tersebut serupa dengan penelitian Khasanah (2015) bahwa melalui penggunaan model pembelajaran Inquiry dapat meningkatkan sikap ilmiah siswa kelas VA SDN Dukuhan Kerten No.58 Surakarta tahun 2014/2015. Bahwa terjadi peningkatan sikap ilmiah siswa dengan penerapan model pembelajaran Inquiry. Persentase ketuntasan siswa dilihat dari siswa yang mencapai kategori mulai berkembang/tinggi dan sudah membudaya/sangat tinggi yaitu sebanyak 27 siswa atau $93,10 \%$ dari indikator kinerja yang telah ditetapkan yaitu $\geq 80 \%$.

Implementasi model pembelajaran Inquiry untuk meningkatkan sikap ilmiah siswa harus memperhatikan langkah-langkah model tersebut agar pelaksanaan nya dapat meningkatkan sikap ilmiah siswa sesuai tujuan yang diharapkan. Adapun langkah dalam pembelajaran model pembelajaran Inquiry menurut (Wening, 2012;13), yakni Observation, Manipulation, Generalization, Verification, dan Aplication.

\section{SIMPULAN}

Berdasarkan hasil pembahasan penelitian yang dilaksanakan dalam tiga siklus dengan enam pertemuan membuktikan bahwa sikap ilmiah siswa dapat meningkat dengan menerapkan model pembelajaran Inquiry dalam pembelajaran IPA siswa kelas V SD Negeri Pawit I No.69 Surakarta tahun ajaran 2017/2018 terlihat dari indikator kinerja pada penelitian ini sebesar $80 \%$ siswa secara klasikal memiliki sikap ilmiah kategori sangat baik yang tercapai pada siklus III pertemuan 2 dengan persentase 88,89\% siswa mencapau sikap ilmiah kategori sangat baik.

\section{DAFTAR PUSTAKA}

Fatonah, Siti \& Prasetyo, Zuhdan K. 2014. Pembelajaran Sains. Yogyakarta: Penerbit Ombak

Gie, The Liang. 1992. Pendidikan Sains. Yogyakarta: Yayasan Studi Ilmu dan Teknologi

Hosnan, M.2014. Pendekatan Saintifik dan Kontekstual dalam Pembelajaran Abad 21. Bogor: Ghalia Indonesia

Khasanah, Uswatun. 2015. Penerapan Mode Inkuiri untuk Meningkatkan Nilai Karakter pada Pembelajaran IPA di Kelas VA SD Negeri Dukuhan Kerten No.58 Surakarta Tahun Ajaran 2014/2015. Skripsi Tidak Dipublikasikan, Universitas Sebelas Maret, Surakarta.

Sukardjo, JS.2005. IImu Kealaman Dasar. UNS : UPT Penerbitan dan Percetakan UNS (UNS Pers)

Susanto, Ahmad.2016. Teori Belajar \& Pembelajaran di Sekolah Dasar. Jakarta: PRENADAMEDIA GROUP 
Suwandi, Sarwiji. (2009). Penelitian Tindakan kelas (PTK) dan Penulisan Karya Ilmiah. Surakarta: Panitia Sertifikasi Guru Rayon 13FKIP UNS Surakarta

Wening, Carl J. (2012). The Level of Inquiry Model of Scince Teaching. USA : Illionis State University 